\title{
SOCIAL SECURITY OF FOREIGNERS IN POLAND - THE LEVEL OF SATISFACTION OF HUMAN NEEDS AMONG IMMIGRANTS LIVING IN POLAND
}

\begin{abstract}
At this moment, the presence of foreigners in our country is one of the important problems affecting society in Poland. The unstable situation on the eastern border with Belarus and numerous attempts to illegally cross the border by emigrants - refugees from, among others, Syria, Iraq, or Afghanistan, are one of the very popular topics of public and media disputes or topics discussed by politicians. This topic is very important and crucial - it concerns first of all respect for human rights in relation to those people. Nevertheless, in Poland, apart from the problem of illegal foreigners, there are also citizens of other countries who reside legally in our country. Currently, it is a growing group, whose members are not citizens of our country, but they are an increasingly important part of our society. Therefore, it is worth taking up this topic and reflecting on the situation of foreigners who reside legally in Poland. The subject of this article is the issue of social security of foreigners staying in Poland. The basic research question to which this article is to answer is the question of whether foreigners legally residing in the territory of the Republic of Poland are guaranteed social security - it means if they have ability to live, survive and develop. The article will use the method of an interview and a survey conducted among foreigners living in our country, as well as an analysis of available documents and sources regarding the situation of foreigners in Poland. The results of the research and analyzes indicate that the situation of foreigners in Poland is relatively correct, but not in all areas the needs of this group are fully satisfied.
\end{abstract}

KEYWORDs: social security, foreigners, human needs, human rights, discriminations 


\section{INTRODUCTION}

In contemporary Poland, the presence of foreigners in our country is one of the important problems affecting society. The unstable situation on the border with Belarus and numerous attempts to illegally cross the border by emigrants refugees from, among others, Syria, Iraq, or Afghanistan, are one of the very popular topics of public and media disputes or topics discussed by politicians. Every day, Polish Border Guards, using social media and other media, informs about numerous tries of crossing border in illegal way. For example, on 18th October 2021, they informed about 612 attempts to illegally break into Poland and that since the beginning of October this number has already exceeded 10,000 (Zygiel, 2021). This topic is very important and crucial - it concerns first of all the issue of respect for human rights in relation to those people but also cover the area of international cooperation and international provisions as well as issue of conflict between Poland, other European Union countries and Belarus.

Nevertheless, in Poland, apart from the problem of illegal foreigners, there are also citizens of other countries who reside legally in our country. Currently, it is a growing group, whose members are not citizens of our country, but they are an increasingly important part of our society. Therefore, it is worth taking up this topic and reflecting on the situation of foreigners who reside legally in Poland.

The subject of this article is the issue of social security of foreigners staying in Poland. The basic research question to which this article is trying to answer is the question of whether foreigners legally residing in the territory of the Republic of Poland are guaranteed social security. It means, we will try to check if those people have ability to live, survive and develop, or in other words, the article will evaluate the level of satisfaction their needs.

The article will use the method of an interview and a survey conducted among foreigners living in our country. In addition, there will be some analyses of available documents and sources regarding the situation of foreigners in Poland.

The results of the research and carried out analyzes indicate that the situation of foreigners who live legally in Poland is relatively correct, but it also must be said that not in all areas the human needs of this group are fully satisfied. There are some fields which needs to be improved in order to have a good level of satisfaction forgivers' needs. 


\section{SOCIAL SAFETY AND SECURITY}

Social safety and security is an important issue. The term of social safety and security is defined in various manner. Skrabacz and Sulowski state that it is "protection of the existential basis of human life, ensuring the possibility of satisfying individual needs (material and spiritual) and fulfilling life aspirations by creating conditions for work and study, health protection and pension guarantees" (Skrabacz, Sulowski, 2012, p. 7). Such-Pyrgiel and Dzurzyński are pointing out that social safete is described as some kind of protection against economic and social misery which cause various social risks, such as: sickness, old age or unemployment, and other situations which do not let people to take care of their needs by earnings from work (Such-Pyrgiel, Dziurzyński, 2015, p. 141, pp. 143-144). In addition, taking into consideration different studies on social safety and security, we can conclude that the phenomenon of social safety and security may be understood as a state - the permanent situation in which an individual and society have the ability to live, the ability to survive, and the ability and the possibility to develop. According to M. Such-Pyrgiel "social security is to guarantee harmony and social order, and thus the absence of conflicts in society, preventing the phenomenon of anomie and social disintegration in the state (...). It also aims to prevent the processes of marginalization and social exclusion related to the possible occurrence of social risks, such as: the risk of old age, unemployment or loss of health" (Such-Pyrgiel, 2013, p. 35-36; com. Such-Pyrgiel, 2014, p. 148-150, com. Barbachowska et al, 2014, p. 179-181).

Taking about the understating of the term safety and security, one can ask how a person can reach this state. This should be done through the process of meeting and satisfying the needs of the individual. It is not a purpose of this studies to go deep into the issue of human needs. But it may be said that according to the very classical theory of human need described by American psychologist, professor at Brandeis University, Brooklyn College, New School for Social Research, and Columbia University, as well as the representative of humanistic and transpersonal psychology - A. Maslow, there are five levels of human needs. 
Figure 1.

Maslow's theory of needs

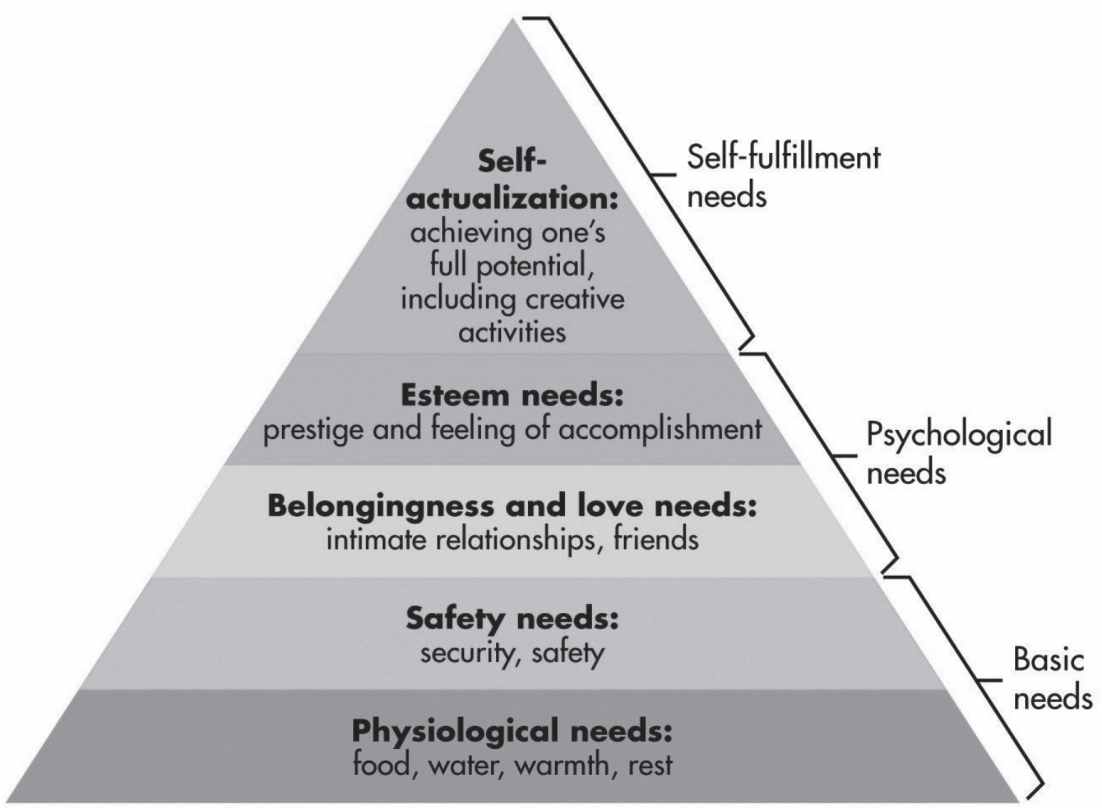

Source: Mcleod, 2020, https://www.simplypsychology.org/maslow.html

Those five types of human needs in form in the shape of pyramid, where the most basic needs are on the bottom and the highest needs on the top. The satisfaction on those needs is a process. They are satisfied gradually and satisfying one level causes the person to feel the need to satisfy subsequent levels. There are:

- $\quad$ physiological needs - for example: food, housing, procreation,

- safety needs - for example: health security, economic security,

- love and belonginess needs - for example: family, friends, acceptance by others, belonging to groups,

- $\quad$ esteem needs - for example - success, prestige, respect,

- $\quad$ self-actualization needs - for example: self-development, abilities, spiritual development (Mcleod, 2020). 
It is important to indicate that the process of satisfying human needs must cover all needs, not only existential but also higher-order needs. A person in order to have a sense of social safety and security, must have not only ability to survive so his or her existential needs have to be satisfied by also, he or she should have opportunity to fully developed his or herself so his or her psychological and self-fulfillment need must be taken care of.

In addition, we must notice that social security is not an option. It is a state which is guaranteed by many different legal acts and declaration - both on international and national level. It is one of the most important human rights. For example, we have provisions regulating this issue in Universal Declaration of Human Rights - "Everyone, as a member of society, has the right to social security and is entitled to realization, through national effort and international co-operation and in accordance with the organization and resources of each State, of the economic, social and cultural rights indispensable for his dignity and the free development of his personality" (United Nations, 1948, article 21). The issue of social security is also mentioned in different convention including International Covenant on Economic, Social and Cultural Rights - "The States Parties to the present Covenant recognize the right of everyone to social security, including social insurance" (United Nations, 1966, article 9) or Convention 102 concerning minimum standards of social security (see: International Labor Organization, 1951). The social security is also guaranteed by the provisions of European Union - "Everyone residing and moving legally within the European Union is entitled to social security benefits and social advantages in accordance with Union law and national laws and practices" (Charter of the Fundamental Rights of the European Union, 2012, article 34) and in the Constitution of the Republic of Poland - "A citizen shall have the right to social security whenever incapacitated for work by reason of sickness or invalidism as well as having attained retirement age. The scope and forms of social security shall be specified by statute. A citizen who is involuntarily without work and has no other means of support, shall have the right to social security, the scope of which shall be specified by statute (The Constitution of the Republic of Poland, 1997, article 67).

To conclude, we have to say, that social security is one of the most important human rights described and guaranteed by numerous acts on the international and national level (see more about social security as one of the human right: 
Sitek, 2017, Banaszak, 2018, pp. 17-18). It must be also said that the Polish Constitution does say only about the right to social security for citizens, but other documents give the right to social security to everyone. Fundamental Chart issued by the European Union has a special importance here because it says about right to social security for everybody who "residing and moving legally within the European Union". It means that those who has not the EU passport but stay legally in any of the EU state, including Poland, has this right. This is why, we can talk about foreigners staying legally in Poland in the context of social safety and security.

\section{Foreigners in Poland}

The statistical data is showing that the number of foreigners living in our country is growing. The research done by Statistics Poland shows that on 31st December 2019, there were 2106101 foreigners living in Poland. This is estimated number given by Polish Statistical Office based on different registrations. Among foreigners living in Poland the biggest group are people from Ukraine $-64 \%$ of all foreigners. The exact numbers by country are as follows:

- Ukraine - 1351418 ,

- Belarus - 105 404,

- Germany - 77073 ,

- Moldova - 37 338,

- Russia - 37 030,

- India - 33 107,

- Georgia - 27 917,

- Vietnam - 27 386,

- Turkey - 25 049,

- China - 23 838,

- Other countries - 360541 (Lis, 2020).

The data about people coming from other countries in Poland is also given by Polish Border Gourds and the Office for Foreigners. Their data is based on the registration of residency permits issue for foreigners. By the end of third quarter of 2021, according to data publish on 26th October 2021, the 
offices in Poland issued 525000 residence permits. Among total numbers of people who had valid residence permits on 1st October 2021, the largest groups were citizens of:

- Ukraine - 293 800,

- Belarus - 37 100,

- Germany - 19 700,

- Russia - 13.700,

- Vietnam - 11 200,

- India - 10 900,

- Georgia-9600,

- Italy - 8500 ,

- Great Britain - 6900

- China - 6900 .

In the first three quarters of the year, the number of foreigners with valid residence permits increased by 68000 . people. The highest increase among foreigners settling in Poland concerned the citizens of:

- Ukraine - by 49 700,

- Belarus - by 8400 ,

- Georgia - by 1700 ,

- Moldova - by 1300 ,

- India - by 1100 (Urząd do spraw Cudzoziemców, 2021).

Based on the presented statistical date coming from issued documents of residency as well as from estimation done by Statistical Office, we have to notice that number of foreigners living in Poland is increasing. Only in this year, the number of people with valid residency card growth by almost $13 \%$. Also, taking into consideration the estimated number of all foreigners which is more than 2 millions, we gave to say that it is more than $5 \%$ of all population living in the territory of Poland. It means that these number are pretty significant, and foreigners compose important part of our society. Therefore, it is worthy to see how their need are being satisfied or if they have sense of social safety and security. 


\section{THE RESEARCH - PURPOSE AND METHODOLOGY}

As it was mentioned above, the social security is an important issue. The needs of every group of society should be satisfied. It is necessary condition to have healthy and properly functioned society. One of the groups which is at risk of being unable to meet their needs are foreigners who legally reside in the territory of the Republic of Poland. We have to add that due to the special situation of the covid pandemic19, the level of meeting their needs and, consequently, the sense of social security may have decreased.

It can be said, that one of the biggest pathologies is that a person legally residing in a given country experiences various kinds of barriers that prevent them from satisfying their needs and thus their sense of social security is endangered.

The basic research question to which we wanted to receive an answer was the question of whether foreigners legally residing in the territory of the Republic of Poland are secure - that is, whether the have ability and possibility to survive and develop. In order to evaluate this issue, the methods of survey and interview were conducted. As a result of these activities, we obtained results based on 53 interviews and 237 questionnaires. When developing the interview sheets and the questionnaire, we relied on the assumption that the sense of social security is, above all, the possibility of satisfying needs. Therefore, the questions were focused on five areas related to the five levels of human needs according to Abraham Maslow's pyramid of needs.

It must be noticed that the research has a reference nature only. The group of foreigners chosen for those interviews and questionnaires cannot be called representative group. The purpose of this research is to shows some facts and trends. Due to the lack of selection of a representative group, the study does not pretend to be a study that presents the problem in a comprehensive manner.

It also must be added that the research was done with the cooperation of group of students with whom the author of this study conduct the classes "Pathologies of social life in contemporary Poland" (group of Alcide De Gasperi University of Euroregional Economy Management students: Asaduddin Mohammed, Bhatia Priya, Chettiar Sebastin, Dave Utkarsh, Gurung Roshma, Khanal Aakash, Labana Gurjitkaur, Labana Manmeetkaur, Makwana Jigar, Nair 
Mrinal, Patel Shivam, Rathee Deepak, Sahukhale Jesmine, Shenai Aishwarya). This cooperation cover two areas - first of all, those students are foreigners staying legally in Poland and therefore their experience gave us a research data. Secondly, they were helpful in the process of collecting data for the research.

The research group included both men and women, mostly relatively young people (up to 35 years of age). Most of them are educated, at the bachelor's or master's level. Most of them are people without families and children, living in large or very large cities in Poland. Among the respondents, the largest group are people combining work and studies. In addition, their monthly income is mostly at the level of PLN 1800-3000 and the source of income is work and support from the family staying in home country. The period of stay of these people in Poland is between 7 months and 5 years, most of which are people living in Poland for 2-3 years. For about half of the respondents, the stay in Poland is the first experience of a longer stay abroad (over 3 months).

\section{Situation of foreigwners living in Poland}

As it was said, the questions were focused on five areas related to the five levels of human needs according to Abraham Maslow's pyramid of needs. We want to check and evaluate if foreigners in Poland are able to satisfy their need and what is the level of their satisfaction.

One of the aspects of the sense of security is the legal stay in the territory of the Republic of Poland. The legal stay means also that a person is able to receive different type of residency permits such as visa, work permit, residency and work, temporary residence card or permanent residency card. Most of the respondents indicate that the process of applying for a visa or residence card is complicated, very long, not entirely clear, not very predictable, and the rules and regulations are very freely interpreted and frequently changed. The most frequently indicated obstacles and barriers are:

- processing time: in many cases the process of getting the decision is much longer than it should be and than it is indicated in procedures: there were some cases that people were waiting for decision more than year and the appeal process is taking sometimes more than two years, 
- no communication in English: foreigners point out that many officer working in offices dealing with legal stay do noy know or they are not willing to speak one of the most universal language, which is English,

- not clear interpretation of regulations and provisions: foreigners point out that they feel like the office is using each and every excuse to grant the rejection based on not clear interpretation of provisions - as a proof they are showing to facts that the first level they got the rejection and then in long appeal process the higher office agreed to their arguments and gave the right to stay in Poland.

The average overall score in this area (rate the process of obtaining legal residence in Poland on a scale of 1-5) is 3,14. It must be said that some of the issues and problems are of big importance. For example, the issue of time to obtain or extend the legal stay cause problems. While the application is in process, the foreigner is legal in our country, but they cannot travel outside of Poland for example to take care of important issues in their home country. They can leave Poland but without valid residency card, they are not able to comeback. Some responders said that for example they could not attend the funeral of their family members back at home - they did not want to quit studies or job and travel to home country even for few days would cost them lack ability to be back.

Also, the conducted research attempt to make the general assessment of the sense of economic security, the satisfaction of existential needs and health security. The responders were asked to evaluate particular issue on the rating scale from 1 - very poor to 5 - very high level of satisfaction. The overall assessment of working conditions and job satisfaction is 4,15 , The overall assessment of the housing conditions in Poland which are affordable for them is on the level of 3,9. We were asking also for overall assessment of economic stabilization is 4,05 . Foreigner were also asked to evaluate the area of medical security. The assessment of access to medical care is 3,67 and the biggest problems here are prices and the issue of communication for people who do not speak Polish. Many of them show that in order to get proper medical treatment they were pushed to go back to home courtiers.

The next area which was evaluated in this research was issue of security. The general sense of security in Poland, in the subjective opinion of the responders, 
using the scale from 1 to 5 , is at the on level of 3,81 . The foreigners ask for details are pointing out to some of the most important threats such as:

- fear of losing a job,

- reduction in hours due to the pandemic,

- $\quad$ issues related to worse treatment, due to origin, religion, and culture.

The problem which threatens the sense of security is discrimination and unequal treatment due to the fact of being a foreigner, different skin color, or origin from a different tradition or religion. As many as $57 \%$ of the respondents indicated that they had encountered discrimination at least once, of which $38 \%$ indicated that it happened at work or at school A physical attack due to being a foreigner was experienced by $19 \%$ of respondents and verbal attacks by $53 \%$.

An important element of the feeling of social safety is the issue of meeting the need to belonging. Most of the respondents have regular contact with their families in their country of origin, although this contact is primarily remote. Most of the respondents - 95\% have the opportunity to practice their religion. The situation is worse when it comes to access to participation in events related to traditions and culture - here $57 \%$ of respondents have access, but the problem is that there is no organization of such events.

Most of the respondents positively assess their relations with Poles - the overall rating on a scale of 1-5 is 4,1). The respondents also assessed the openness of Poles to „otherness” related to origin and here the overall assessment is at the level of 4.3 .

The problem, however, is the issue of communication. In this area, the overall score is 2,81 . Only a small group - 9\% indicate that the problem here lies in the mentality of Poles or in being closed to others. Most of them indicate that the problem is the language - foreigners do not learn Polish and Poles speak English poorly.

In order to have a chance for full development, the satisfaction of needs of the higher order is necessary and crucial. The foreigners living in Poland primarily focus on ensuring that their lower order needs are satisfied - physiological, safety and belonging. Only a small group of them declares that they expect the possibility of fuller development and cares about satisfying such needs as respect, recognition, prestige, and self-development. When they 
were asked if their stay in Poland gives them development opportunities, as many as $76 \%$ answered positively. Most of the respondents answered that this development was primarily about access to education and the possibility of getting an education - which was a problem in their country of origin. In addition, we asked very general question to make the overall assessment of the subjective sense of happiness - the question was are you happy in Poland. In this case they were asked to give the mark on the scale from 1 - very unhappy to 5 - very happy. The average mark here is 3,81 . The majority $-76 \%$, indicate that they feel appreciated in Poland in connection with the performance of professional duties or while they are studying.

Because currently we are living in very special time - it means during the pandemic covid 19, it was justified to ask how this problem impact their sense of social safety and security. When it comes to the threat related to the pandemic, the respondents first of all indicate to the uncertainty related to keeping a job. Some of them have already lost their jobs or their terms and conditions have been significantly changed - for example termination of the employment contract and signing the free agent contract, reduction of the number of hours, long breaks at work. This fear also applies to the fact that the priority in employment will be for Polish citizens, and it will be much more difficult for a foreigner to be employed. Before the pandemic, a foreigner often got a job because it was cheaper for company owner and the foreigners could be paid less than a Pole. Currently, due to the growing unemployment, there will be more Poles who will take a less-paid job and a foreigner will be left without a basic source of income. The respondents also point to the fact that the situation in their country of origin has worsened and that therefore they cannot count on help from their family, or the help is much smaller.

Another threat is access to medical assistance. Many respondents point to concerns that if they fall ill, they will not be able to afford or receive medical care.

Another group of threats was related to travel restrictions. The necessity to perform tests generates additional costs - for example a PCR test at the airport in Warsaw costs PLN 520 - 620 PLN. In addition, restrictions in air transport or the need for quarantine are a big problem. Often, there is also a fear that after leaving Poland, they will not be admitted to it. 
Considering the issues related to pandemic, many foreigners point out to one area, in which according to them, in Poland they are feeling much more secure and safe than they could feel in their own countries. Respondents were showing that in Poland they have bigger chance to get vaccinated. In many of their countries of origins, citizens experience huge shortage of possibility to be vaccinated. In Poland, each foreigner could easy get vaccine and this fact strongly increase their sense of safety, especially in the area of medical security.

The issue of general security and safety was also a topic of another research done by portal morizon.pl. The report from this research titled "Foreigners in Poland. Are Polish cities open-minded?". The research was done in few main cities in Poland, including Warsaw, Łódź, Cracow, Tri-City, Wrocław, Poznań, Katowice, Bydgoszcz. The results are showing that Poland is a very popular choice for foreigners, and they are coming to our country mostly for two main reasons: job and studies. In this research, foreigners were evaluating several areas and they gave the notes on the scale from 1 to 6 . The overall result of this very interesting research is present on the below figure.

Figure 2:

Evaluation of Polish cities by foreigners

\section{How do foreigners rate Polish cities?}

\begin{tabular}{|c|c|c|c|c|c|c|c|c|}
\hline & 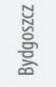 & 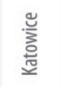 & 总 & 搃 & 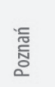 & 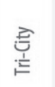 & $\begin{array}{l}\text { 3. } \\
\text { 总 } \\
3\end{array}$ & 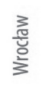 \\
\hline Safety & 4,4 & 4,28 & 5,07 & 4,02 & 4,99 & 4,8 & 4,87 & 4,67 \\
\hline Costs of living & 4,62 & 4,44 & 4,25 & 4,83 & 4,59 & 4,12 & 4,09 & 3,83 \\
\hline Potential & 4,13 & 4,56 & 4,28 & 3,77 & 4,32 & 4,58 & 4,51 & 4,5 \\
\hline Modernity & 3,58 & 3,77 & 3,14 & 3,49 & 3,96 & 3,64 & 3,49 & 3,77 \\
\hline Friendly attitude & 3,87 & 4,02 & 4,14 & 3,7 & 4,41 & 4,14 & 3,82 & 4,35 \\
\hline Aesthetics & 4,19 & 3,42 & 4,11 & 3,15 & 4,29 & 4,02 & 4,44 & 4,18 \\
\hline Tolerance & 3,63 & 3,84 & 3,61 & 3,14 & 3,84 & 3,41 & 3,4 & 3,8 \\
\hline Culture / Pastime & 3,56 & 4 & 4,66 & 4,36 & 4,46 & 4,19 & 4,36 & 4,55 \\
\hline Ecology & 3,25 & 2,28 & 1,6 & 3,17 & 3,78 & 3,69 & 2,6 & 2,9 \\
\hline
\end{tabular}

Source: Stulin, J., 2017, in: https://www.morizon.pl/blog/foreigners-in-poland 
This research was done in 2017. For sure, there are some changes due to the fact of pandemic, but main outcomes are still current. The general conclusion of this research may be described in few main point. First of all, it may be state that foreigners coming to Poland quickly become part of society by finding a job or choosing to study at local universities. Secondly, the respondents believe that it is safe in Polish cities - in this category, the average score on a 6-point scale is 4.63. Thirdly, despite the faster development and considerable potential, Polish cities are still not considered modern in the eyes of foreigners. Also, although the foreigners consider Poles to be friendly (average 4.05), we still have a problem with tolerance. Foreigners still faced the racism and discrimination in every city. The last issue is a problem with communication due to language. Foreigners practically do not know Polish. They also often complain about the level of English among local residents (Stulin, 2017).

\section{Conclusion}

The foreigners in Poland become very important and crucial part of our society. Currently, media and other sources are talking about foreigners a lot but mainly they are focusing on those who are trying to come to Poland illegally as immigrants or refuges. There is not much discussion about foreigners who are already in Poland and who are staying in our country in legal way. It is obvious that migration problems or even, as it is called by some expert, migration crises that we are facing now are important, we cannot forget about those other foreigners who already become part of our society.

The healthy and properly functioning society is a base of each and every country. But in order to get to such state, each and every part of this society must feel safety and security in social sense. It means that all members of society must get the opportunity and ability for living, surviving, and developing. The only way to reach to that point is to be sure that all needs of society are satisfied. This statement also applies to foreigners staying legally in Poland.

Based on the results of surveys, interviews and direct contact with foreigners living in Poland, it should be said that our country is still a relatively safe place for foreigners. However, if we look at the issue of social security, in general, 
even before the pandemic, it was not easy for foreigners to meet their needs, especially those of a higher order. At present, quite high fears and threats also concern the level of meeting lower-order needs, including existential needs. Most of the respondents focus only on existential and security issues, possibly trying to maintain any social contacts. However, they push the issues related to self-development to the background and to undefined future. Quite a large group of graduates from bachelor's degree planned and even made an initial application to continue their studies at the master's level. Unfortunately - the pandemic and consequently the lack of good employment prospects, salary cuts, reduced number of hours, job loss, less help from the family home meant that those plans for continuing education had to be postponed.

In few first month of pandemic, we notice the decrees of the number of foreigners in our country. But most of them, however, stay in Poland, because despite the problems, they still have a better chance here than in their country of origin. Even a poor job guarantees them survival and at the same time, their home countries will not give them such guarantees.

As it was mentioned before, this studies and research do not claim to show the situation of foreigner in Poland in full and entire approach. The main purpose was to give some ideas how the issue of satisfaction of human need is seen by foreigners living in Poland. Due to the fact that they are becoming the more and more important part of our society, it could be justified to continue this studies and to try to see those problems in much more detailed manner.

The main conclusion - that our country is still a relatively safe place for foreigners - does not mean that everything is right and correct. Some area should be improved. One of the issue that foreigners are facing a lot of problems is the matter of the legalization of stay. Many examples shows that this issue required a lot of improvement because the administration procedures take too much time. The regulations about apply for the extension of legal stay in Poland set the time when the case should be decided. Unfortunately, in most of the situation, the decision on granting or rejection of the right to stay in Poland in first instance takes often more than 6 months and in appeal process, there are cases which take more then one year. Also, this research as well as others shows the issues of intolerance and discrimination in many areas. And there is one more issue to be corrected and improve - communication. In this 
area - foreigners themselves can help. In fact, the level knowledge of English or other international language is not good in Poland. But also, foreigners who want to live, study and work in Poland should consider learning local language. Improving the communication could lead to increasing the sense of social safety and security.

Many people are convinced that a state should first of all take care of own citizens. But the group of foreigners are in Poland legally. They got the permission to stay in our country. Some of them or even most of them contribute to our economy by paying taxes, buying different goods and services, or paying for their studies. Therefore, the social policy implement in our country should also consider the area of satisfaction of the need of these members of society. Therefore, we should focus our attention not only on those poor and suffering refuges but also on those who are already in our country. 


\section{REFERENCES}

Banaszak, A. (2018). Welfare as a Form of Ensuring the Social Safety of Society and an Effective and Successful Tool in Election Campaigns (Thoughts Based on the Situation in Contemporary Poland). Regional Formulation and development studies, 3(26). Klaipeda: Klaipeda University - Faculty of Social Sciences and Humanities.

Barbachowska, B., Dziurzyński, K., Such-Pyrgiel, M., Szejniuk A. (2014). Bezrobocie a bezpieczeństwo społeczne. Analiza zjawiska na przykładzie powiatu podwarszawskiego. Journal od Modern Science vol. 21/2/2014, pp. 179-209.

Charter of the Fundamental Rights of the European Union. (2012). Official Journal of the European Union of 26.10.2012, C 326/02.

International Labour Organization. (1952). Convention 102 concerning minimum standards of social security. In: http://www.ilo.org/dyn/normlex/en/f?p=NORMLEXPUB:12100:0::NO::P12100_ILO_CODE:C102 (access: 27.10.2021).

Lis, M. (2020). GUS podał szacowana liczbę cudzoziemców w Polsce. Przekroczyła dwa miliony. In: Business Insider - https://businessinsider.com.pl/twoje-pieniadze/ praca/liczba-cudzoziemcow-w-polsce-to-ponad-dwa-miliony-gus-podal-dane/ ydbgxy9 (access: 10.10.2021).

Mcleod, S. (2020). Maslow's Hierarchy of Needs. In: Simple Psychology - https://www. simplypsychology.org/maslow.html (access: 10.10.2021).

Skrabacz, A., Sulowski, S. (2012). Bezpieczeństwo społeczne. Pojęcia, uwarunkowania, wyzwania. Warszawa: Elipsa.

Stulin, J. (2017). Foreigners in Poland. Are Polish cities open-minded? In: https://www. morizon.pl/blog/foreigners-in-poland (access: 27.10.2021).

Such-Pyrgiel, M. (2013). Bezpieczeństwo demograficzne społeczeństwa polskiego w kontekście zjawiska singli w: M. Such-Pyrgiel red., Bezpieczeństwo społeczne w XXI wieku w ujęciu socjologicznym, pedagogicznym, prawnym i nauk o zarzadzaniu. Wyd. WSGE, Józefów, pp. 33-52.

Such-Pyrgiel, M. (2014). Legal changes against the family and single people in twenty first century in Poland, Annales Universitatis Apulensis Series Jurisprudentia vol. 17/2014 pp.148-156.

Such-Pyrgiel, M., Dziurzyński, K. (2015). Bezpieczeństwo społeczne. Leksykon Bezpieczeństwo. Wybrane pojęcia. ed. P. Chodak. Józefów: WSGE Publishing House. The Constitution of the Republic of Poland. (1997). Journal of Laws, No 78, Item 483 (Dz.U., Nr. 78 poz. 483). Text in English language in: http://www.sejm.gov.pl/prawo/ konst/angielski/kon1.htm (access 27.10.2021).

United Nations, (1948). Universal Declaration of Human Right. In: https://www.un.org/ en/about-us/universal-declaration-of-human-rights (access 27.10.2021).

United Nations, (1966). International Covenant on Economic, Social and Cultural Rights. Adopted and opened for signature, ratification, and accession by General 
Assembly resolution 2200A (XXI) of 16 December 1966 entry into force 3 January 1976, in accordance with article 27. In: https://www.ohchr.org/en/professionalinterest/ pages/cescr.aspx (access: 27.10.2021).

Urząd do spraw Cudzoziemców (2021). Zezwolenia na pobyt po III kwartale. Official webside of UdsC - https://udsc.prowly.com/161616-zezwolenia-na-pobyt-po-IIIkwartale (access: 27.10.2021).

Zygiel, A. (2021). Ponad 600 prób nielegalnego przekroczenia granicy polsko-białoruskiej. W: Portal internetowy Radio RMF 24 - https://www.rmf24.pl/raporty/ raport-stan-wyjatkowy/news-ponad-600-prob-nielegalnego-przekroczenia-granicy-polsko-bia,nId,5591300\#crp_state=1 (access: 27.10.2021). 